\title{
United States-Mexican Scientific and Cultural Relations
}

\author{
By Donald D. Brand
}

\section{The Study of History}

T HE oldest and strongest fields of scientific and cultural relations between the United States and Mexico have been history and anthropology. Ever since William H. Prescott's History of the Conquest of Mexico appeared in 1843, Americans have been delving into the history and prehistory of our neighbor to the south. Between 1845 and 1853 the United States acquired more than half of the lands of the Mexican Republic, and research in southwestern history was perforce research in Mexican history. H. H. Bancroft in the 1880's provided the bibliographic groundwork, and shortly after the turn of the century Mexican history became established in a number of colleges and universities in the United States and has had a growing interest since then. Among all courses taught on Mexico in American institutions history leads, and it leads in the number of specialists, of students, and of institutions having courses on Mexico.

This long-continued interest and stress has resulted in the acquisition of Mexican historical materials at several centers in the United States (such as the University of Texas, the University of California, the Library of Congress, and the New York Public Library) which are equaled or exceeded only in Mexico City, Sevilla, Madrid, and Rome. The building of these collections has produced much ill feeling in Mexico toward the United States. Although some Mexicans have stated that many valuable documents probably would now be lost or not readily available for scholarly research had they not been acquired by North American institutions, nevertheless it must be admitted that a very large number of items were obtained by unethical means.

Because a command of Spanish is basic to research in Mexican history, and because most of the scholars in the field have visited Mexico frequently to consult libraries and archives, probably more historians in the United States have friends and acquaintances in Mexico than has any other professional group. This has led to membership in each other's professional societies and representation on the editorial boards of each other's publications. In this connection there should be mentioned the Who's Who in Latin America initiated in 1935 by the late Percy A. Martin, professor of history at Stanford University, which is now in its third edition. Also, the historians (together with the professors of language and literature) commonly constitute the core of the various inter-American or Latin-American institutes, schools and committeeswhether the stress be on Mexico or over all of Latin America.

\section{Accomplishments and deficiencies}

Among the greatest accomplishments of the modern school of historians is the production of textbooks with a sympathetic treatment of the Roman Catholic missionaries and a less nationalistically biased account of Mexican-American relations, as in the writings of such men as Bolton, Priestley and Parkes. Unfortunately there are still current quite biased texts, both in the United States and in Mexico. It should be stressed 
that although there are many students of Mexican history in the United States, there are practically no Mexican workers in United States history. Also, it should be noted that most American work in Mexican history has been concerned areally with the so-called "Spanish Borderlands" and temporally with the Spanish colonial period and with the main periods of stress between Mexico and the United States. The University of California and the "Bolton school" have dominated American work in the history of Mexico. The University of Texas leads in its attention to independent Mexico. It is indicated that American historians should devote more attention to the internal developments of independent Mexico, and that some Mexican historians should work in the history of the United States.

\section{Anthropology and Allied Studies}

Anthropologic interest and research in Mexico by American scholars is as old as the historical. This interest can be dated effectively from the appearance of John L. Stephens' Incidents of Travel in Central America, Chiapas, and Yucatón (which described Mayan ruins) in 1841, and from the various works of Brantz Mayer (which stressed the archaeology of the Valley of Mexico) from 1844 to 1856. The initial stress on prehistory and archaeology has continued to this day.

\section{Archaeology}

Since archaeology dominates the anthropologic work, we will devote special attention to it. Despite the great amount of field work that has been accomplished since 1928, most of Mexico is unstudied archaeologically. The Carnegie Institution of Washington for many years, through its Division of Historical Research under A. V. Kidder, has carried out a comprehensive study of the Mayan area, chiefly in Yucatán.
Archaeology has been stressed, and an encyclopedic approach to an understanding of the area and its people has been adopted in which many institutions and fields have been representedsociologists and philologists from the University of Chicago, physiologists and physicians from Harvard University, botanists and zoologists from the University of Michigan, geographers from Clark University and the University of Florida, and so on. In recent years the C. I. W. has transferred much of its work to Guatemala. The Department of Middle American Research of Tulane University has acted as a clearing house on Mayan studies, and in 1940 produced and distributed the second edition of a map showing all known archaeologic sites in the Maya area. Since 1939 a joint National Geographic SocietySmithsonian Institution expedition, under Dr. M. W. Stirling, chief of the Bureau of American Ethnology, has operated annually in southern Veracruz and adjacent Tabasco and Chiapas. Here were discovered the giant sculptured heads and magnificent stone jewelry of the so-called Olmec or La Venta culture. Little recent work has been done by Americans in the Mixtec and Zapotec prehistoric cultures of the Valley of Oaxaca, but during the past twenty years Dr. Alfonso Caso and other Mexicans have made the area from Monte Alban to Mitla one of the best known in Mexico. In the area within a radius of 70 miles from Mexico City there has been the greatest concentration of archaeologic work in all Mexico. This has been done chiefly by Mexicans, but very important work was accomplished from 1928 to 1936 by Dr. George Vaillant and his wife of the American Museum of Natural History.

In the remainder of Mexico, to the north and west, most of the archaeologic work has been surface reconnaissance with a few stratigraphic trenchings and 
partial excavations. Most of this work has been accomplished since 1928 and by North American institutions. Among the more important enterprises have been the surveys and excavations sponsored by the University of California from 1928 to date, from Lower California and Sonora to Michoacán. The work done by Dr. Isabel Kelly at Apatzingán, Michoacán, is an excellent example of co-operative work. This work was begun at the invitation of the Mexican Government; finances and other aid were supplied by the University of California, a Guggenheim fellowship, the Institute of Andean Research (with financial help from the Office of the Coordinator of InterAmerican Affairs), the Carnegie Institution of Washington, and the American Philosophical Society; and the publication of the report was financed by the Viking Fund which had been established by the Swedish capitalist, Wenner-Gren.

Probably the outstanding contributions made by American archaeologists have been in clarifying Mayan chronology, unraveling the Archaic or Middle Cultures period in the Valley of Mexico area, establishing the Olmec or $\mathrm{La}$ Venta culture on a sound basis, and in reconnaissance of the north and western three-fifths of Mexico. Mexican archaeologists have not worked in the United States, but this is easily explained since (1) Mexican archaeology is more interesting, (2) there are no great private universities or wealthy foundations to finance such work, and (3) there are not enough trained archaeologists for Mexico's own needs.

\section{Ethnology}

Comparatively little has been done in the other anthropologic fields. Ethnology, in all of its branches, would rank next to archaeology. Until recently most of the American ethnologic work in Mexico was carried out sporadically by individuals, such as Guggenheim fellows (e.g., J. Frank Dobie: Folktales in Northern Mexico, and E. H. Spicer: Yaqui Communities of Arizona and Sonora) and persons supported by a university or museum (e.g., Ruth Bunzel of Columbia in Chiapas in 1937, Bronislaw Malinowski of Yale in Oaxaca in $1940-41$, and A. L. Kroeber, for the Southwest Museum, among the Seri in 1930). More ambitious undertakings have been the studies of various Mayan peoples by the Carnegie Institution of Washington, Tulane University, and the University of Chicago. However, the most intensive and at the same time most co-operative project is that for the Tarascans in Michoacán. This began in 1939 as a co-operative project between the University of California at Los Angeles and the Department of Anthropology of the National Polytechnic Institute in Mexico City. By 1940-41 the National Institute of Anthropology and History and the Department of Indian Affairs had entered the program, and many aspects of Tarascan life-from linguistics and nutrition to household arts and social organization-were being studied. This program was taken over in 1943-44 by the Institute of Social Anthropology of the Smithsonian Institution and the Mexican National School of Anthropology and History. From 1944 to 1946 graduate students were trained in various anthropologic and geographic techniques in Mexico City, and they also participated in ethnologic, archaeologic, and geographic field work in the Lake Pátzcuaro area.

Altogether, the chief American contributions during the past twenty years have been (1) the training of Mexican ethnologists in American and Mexican institutions, (2) the making of ethnographic collections representative of various of the more primitive cultures, 
and (3) studies among such peoples as the Seri, Tarahumar, Cahita, Huichol, Tarascans, Otomi, various Mexican groups, Mixtecs, Zapotecs, Mixe, Popoloca of Veracruz, and various Mayan groups. In Indian Mexico it is difficult to draw the line between ethnologic and sociologic studies. The University of Chicago, the Carnegie Institution of Washington, the University of California and the Smithsonian Institution have sponsored or published a number of such borderline studies of Mexican communities, among which might be mentioned Mitla (Oaxaca) by Parsons and Chan Kom (Yucatán) by Redfield. Another important accomplishment was the founding of a Mexican Folklore Society in 1938 under the stimulus of Professor Boggs of the University of North Carolina, who first lectured in Mexico City in the summer of 1938 and who has more recently been a visiting lecturer at the National School of Anthropology.

\section{Linguistics}

The Indian linguistics of Mexico have attracted American scholars for many years. The recent years have been no exception. Individuals affiliated with the Carnegie Institution of Washington, the Smithsonian Institution and the Summer Institute of Linguistics in Oklahoma, and the universities of California, Chicago, Columbia, Harvard, Pennsylvania, and Yale, have accomplished much in three chief fields. Linguistic analysis and classification leading to the postulation of relationships has resulted in the clarification of many problems in filiation, especially for the Uto-Aztecan, Otomian, Mayance, and Zapotecan families. The comprehensive classifications by J. Alden Mason of the University of Pennsylvania and W. Jiménez Moreno of the Mexican National School of Anthropology have been outstanding. Field work in the acquisi- tion of texts, grammars and vocabularies has been carried out among many groups-from the Seri and Papago of Sonora to the Mayans of the Yucatán peninsula-by such workers as Angulo, Andrade, Ecker, Johnson, Kroeber, Lathrop, McQuown, Mason, Newman, Pike, Radin and Swadesh. Improved techniques for the study and for the teaching of Indian languages have been developed, especially by the Summer Institute of Linguistics group and by Americans (such as Swadesh, McQuown, and Barlow) working with the Mexican National School of Anthropology and the Department of Indian Affairs. A large-scale attempt to teach various Indian groups in the native tongues is now under way, especially among the Tarascans, Mexicans, Otomi, and Mayans. A general linguistic text in Spanish by Swadesh, primers in several languages, and technical instruction to the various groups of bilingual teachers are outstanding accomplishments.

\section{Physical anthropology}

Among the four main divisions of anthropology undoubtedly physical anthropology has seen the least activity by Americans in Mexico. Nevertheless, the far-reaching influence of Hrdlicka of the United States National Museum until his death, and of the Hootonian group of physical anthropologists at Harvard, has been experienced in Mexico. Fairly recent work has been done by the Carnegie Institution of Washington in the Mayan area, by Carl Seltzer of Harvard among the Yaqui, and by M. Goldstein of Texas among Mexicans in Texas, Nuevo León, Coahuila and Guanajuato. In 1945 Dr. T. Dale Stewart, of the United States National Museum, taught osteometry at the National School of Anthropology, and at the moment the recently discovered bones of ancient "Tepexpan Man" are being studied by 
Mexican and American anthropologists at the United States National Museum.

\section{AIDS to Exchange of INFORMation}

\section{Financial}

I have stressed anthropology in this discussion for a number of reasons. Mexico has the largest block of American Indian population of any country in the world, and anthropologists have made the study of Indians one of their preoccupations. Mexican leaders believe that anthropology and anthropologists can be of great service to Mexico, and in Mexico City exists one of the few governmentally supported schools of anthropology in the world. The Rockefeller Foundation has given this school, through its parent organization, the National Institute of Anthropology and History, grants for the period 194148 which are utilized for the salaries of the staff and visiting professors, for Mexican and foreign scholarships, and for the library. Here also was founded, in 1944, the first foreign Institute of Social Anthropology of the Smithsonian Institution with funds from the Interdepartmental Committee on Cultural and Scientific Co-operation of the United States Government. Mexican members of this school have received Guggenheim and other fellowships for study in the United States. Many American archaeologists, ethnologists, philologists, folklorists, physical anthropologists, and human geographers have been visiting professors and decturers in this school, and various members of the school's staff have been visiting professors and lecturers in such institutions as the universities of Washington, Texas and Chicago.

\section{Conferences and field work}

Probably the professional anthropologists of Mexico and the United States are personally acquainted with each other to a greater extent than is true of any other profession or discipline. The explanations of this are numerous. It is impossible to do basic anthropologic research in an armchair or a library. Many Americans have spent numerous field seasons in Mexico. Mexican anthropologists have studied at our leading institutions (especially Harvard, Columbia, Chicago and California), and a growing number of Americans are obtaining higher degrees in anthropology in Mexico. Anthropologists are gregarious creatures and hold frequent regional, national, and international conferences and congresses. The International Congress of Americanists, although theoretically open to many fields, is dominated by anthropologists. The 1928 New York and 1939 Mexico meetings of this congress and their proceedings will illustrate this statement. The Mexican Society of Anthropology, founded in 1937, has held four round tables or conferences since 1941. These are essentially Mexican-North American conferences centering on some special topic, as the 1943 meeting in Mexico City which discussed the relationships between southwestern and southeastern United States and Mexico. In 1940 a group of eighteen Mexicans attended the Coronado Cuarto Centennial Celebrations and the Chaco Canyon Anthropological Conference in New Mexico. Many Americans belong to the various Mexican anthropological societies or subscribe to their publications, and the reverse is true also, although there are fewer Mexicans. A Mexican anthropologist, Dr. Alfonso Caso, now a cabinet member, is the only Latin-American member of our National Academy of Science. Three inter-American organizations are concerned greatly with anthropology: the Pan-American Institute of Geography and History (with headquarters in Tacubaya, Mexico, since 1928-29) which publishes an anthro- 
pologic bibliographic bulletin and numerous anthropologic monographs; the Inter-American Indian Institute (with headquarters in Mexico City) which grew out of the first American Indian Congress at Pátzcuaro, Mexico, in 1940; and the Inter-American Society of Anthropology and Geography (with a secretarial office in Los Angeles and publishing center in Mexico).

\section{Knowledge of the people and language}

A greater number of American professional anthropologists probably know Mexico and Mexicans better than do the members of any other American profession. This is because they commonly have the Spanish and now and then an Indian language, travel and work widely over Mexico, and have protracted periods of contact with the common and typical Mexicans, the rural mestizos and Indians. Tourists, businessmen, historians, artists, teachers of Spanish and literature, journalists, and others commonly do not stray far from the main lines of transportation and the larger centers of population, wealth, culture, industry, commerce, and recreation. It should be emphasized here that urban Mexico (especially Mexico City) and the wealthy and intelligentsia classes are not typical of Mexico. Most Americans return from a sojourn in Mexico with woefully inadequate conceptions of Mexico and Mexicans, and especially of what Mexicans really think of the United States and her citizens. Contact only with the intelligentsia is misleading because this class has the largest percentage of persons who are genuinely friendly toward the United States. Furthermore, the average American visitor (be he tourist or professor) is not apt to meet many of the conservative and fervently Roman Catholic intelligentsia who commonly are Anglophobes and Francophiles. And even. when such gentlemen are encountered they usually are too courteous to express their true feelings to or before the visiting American.

Typical Mexico is expressed in the small town or village merchant, farmer, and laborer. If one, after a considerable sojourn, has won the friendship and confidence of such people, then, and then only, will philosophy and religion and economics and international relations be discussed with frankness. From my own personal experiences and from those of friends, it seems apparent that the average Mexican-the "man in the street" or "the man of the village"-is a hardworking, frugal, honest, and religious person who has decided ideas about the United States and North Americans. He believes the United States to be an exceedingly rich and powerful country inhabited by a people with no political and economic morals and few of any other description. The United States to him is a nation of materialistic atheists, with some heretical Protestants and a few rather poor or unorthodox Roman Catholics. If Americans come to Mexico, it must be to flaunt their wealth or to exploit Mexico and the Mexicans. Nothing altruistic could possibly be ascribed to an American. "You," of course, "are an exception. You are 'muy simpático' and more like a Mexican than a Gringo."

\section{Developments in Geography}

Americans have paid little attention to the geography of Mexico until recently, although travelogues and original maps date back at least to the Mexican War. The first doctoral dissertation on Mexican geography was that on land systems by G. M. McBride at Yale in 1921. Since then there have been ten more, six of which were done at the University of California under Professor Carl O. Sauer. Probably the greatest single American contribution to the study 
of Mexican geography has been the pertinent sheets of the great $1: 1,000,000$ map of Latin America issued by the American Geographical Society. Ranking with this is the aerial photographic map of Mexico made by the United States Army Air Forces in 1942 in cooperation with the Mexican Government. Considerable geographic exploration and mapping of Mexican areas and waters has been done by Americans, but most of it has been by hydrographers and geodesists of the United States Government, geologists, botanists, anthropologists, and the like. The academic or professional geographer has contributed principally in historical and economic studies in Lower California, the border states, Sinaloa, Michoacán, Guerrero, the Valley of Mexico and along the Pan-American highway. John L. Page submitted a dissertation on the climate of Mexico to Clark University in 1929, and in recent years C. W. Thornthwaite has acted as climatologic consultant to the Mexican Ministry of Agriculture which has adopted the Thornthwaite climatic classification. A further indication of the American lack of interest is the fact that no textbook exists in English on the geography of Mexico alone or with the remainder of Middle America. The section on Mexican geography in the various texts on North America or Latin America is usually the poorest in the book. Nevertheless, courses on the geography of Latin America rank after only history and literature among Latin American courses in American universities. It is of interest that in the Aids to Geographical Research, just published by the American Geographical Society, only fourteen American geographers are listed as having a strong interest in Mexico, and six of these only for northern Mexico or for bio-geography.

Despite the Inter-American Society of Anthropology and Geography and the
Pan-American Institute of Geography and History mentioned previously, there is exceedingly little contact between Mexican and American geographers. Not a single Mexican belongs to the Association of American Geographers (although there are several elsewhere in Latin America) or to the American Society of Professional Geographers. Of the score or more Americans who belong to the Mexican Society of Geography and Statistics, only one or two are professional geographers. This is because the membership in Mexican geographical societies (as is true in nearly all of Latin America) comprises chiefly lawyers, historians, diplomats, engineers, anthropologists, literary lights, and other nongeographers. Furthermore, there are exceedingly few professional geographers in Mexico. Considering the great need for regional and national planning in Mexico, it is indicated that a national graduate school in geography, comparable with that for anthropology and history, should be established. Also, geographers would find in Mexico a greater range and contrast in climate, soil, and vegetation, and a greater variety of economies and land settlement patterns than in any other country in the New World.

\section{The Other Social Sciences}

\section{Emphasis on economics}

Of the remaining social sciences, economics is most important. However, most of the academic work done by Americans in Mexican economics until recently has been in economic history (especially of the colonial period) and economic geography, and only four or five doctoral dissertations have been written on modern Mexican economics. Comparatively few American economists are acquainted with the Mexican economists, or with Mexican economic literature and work. In an attempt to remedy 
this situation for economics and the other social sciences, there was instituted in May of 1947 a quarterly journal in English entitled The Social Sciences in. Mexico, published in Mexico City. An attempt to remedy the reverse of the picture is the imposing list of translations into the Spanish sponsored by the Mexican nonprofit organization, Fondo de Cultura Económica. Many contemporary and also classic English, American, and German works in economics, sociology, anthropology, history, political science, philosophy, and so forth, have appeared in the last ten years. In recent years a growing number of American economists have become interested in the fields of Mexican labor organization, agrarian policy, transportation, industry, and finance. In 1928 -29 the Brookings Institution sponsored a survey of Mexican economy; and under the impact of Mexican expropriations of American properties and the more recent experiences of the World War, many economists (representing universities, research institutions, business enterprises, and the United States Government) have been studying the manifold phases of Mexican economy.

Probably the fields of theoretical and applied economics will see a greater growth in the next few years than any other of the social sciences. This has been foreshadowed by the various wartime organizations such as the InterAmerican Development Commission which has reported on the coal and iron deposits of Mexico and on agricultural resources, the Mexican-American Commission for Economic Co-operation, and the Mexican-American Conference on Industries. Recently the Bank of Mexico invited a technical mission from the Armour Research Institute of Chicago to make a survey of Mexican textile, leather, lumber, and coal industries. For several years the Rockefeller Foun- dation and the Mexican Ministry of Agriculture and Development have cooperated in experimental work on seed selection and on raising agricultural returns. In many other fields of applied economics there has been co-operation, chiefly between the governments of the two nations. Among the most rapidly growing fields is statistics, especially demographic statistics.

\section{The younger sciences}

As was mentioned in the section on anthropology, the distinction between sociology and anthropology in Mexico is difficult to determine. Most of the sociologic work to date has been community studies and studies of labor organizations and labor laws. More of this has been done by historians, anthropologists, and geographers than by sociologists. The discipline as such is comparatively new in Mexico. A yet younger discipline is political science. One might say that in Mexico, as in most of Latin America, government or political science is discussed practically everywhere excepting in academic courses on political science. Most of the studies on Mexican government carried on in universities of the United States have been in departments of history, law, and international relations; and most of the dissertations listed under political science have been on the relations between Mexico and such foreign governments as the United States, France, Great Britain, and Texas. Johns Hopkins, the University of Texas, and the University of California have been outstanding in this field. Practically no work has been done by Americans on state and local government in Mexico (although the municipio or township is the legal basic political unit), and the little work done on federal government and national parties has been generally superficial. However, few, if any, Mexicans have done research in the 
state and local governments of the United States. It is indicated that Mexican and North American political scientists should get past the mere reading of constitutions and party platforms.

\section{The Natural Sciences}

In the nature of things, the physical sciences (physics, chemistry, astronomy, and their handmaiden, mathematics) seldom have regional identity or individuality. Consequently, few contacts have been established between the Mexican and American scientists in these fields. However, since there have been comparatively few opportunities for technical training in these fields in Mexico until recently (other than in mathematics, which has a long and honorable history in Mexico), many Mexican physical scientists have been trained in the United States. 'The' first Mexican citizen to hold a Guggenheim fellowship was the physicist Manuel Sandoval Vallarta in 1927 while a member of the faculty at the Massachusetts Institute of Technology. The first Mexican Guggenheim fellowships were granted in 1930 - one each in mathematics and medicine. $^{1}$ Due primarily to the initiative of astronomers, physicists, and mathematicians at Harvard and M. I. T., there is a growing relationship in these fields which has found expression in, among other things, the aid given to the National Astrophysical Observatory near Tonanzintla, Puebla, which was dedicated in February of 1942. Also, Mexican physicists trained in the United States have been promised aid in their atomic research, which may be accelerated by the development of uranium

1 Since the Guggenheim fellowships were initiated in 1925, some 30 Americans have studied in Mexico (chiefly in the biological sciences, the fine arts and literature, and anthropology), and some 40 Mexicans have received fellowships (principally in the fine arts and literature, medicine and biology, and physics and mathematics). deposits in Chihuahua. Chemistry is just beginning as a research science in Mexico, and this chiefly from the stimulus of Spanish refugees in the 1930's and the cutting off of contacts with Germany during the past war.

In the geologic and biologic sciences there is a long history of relationships between the United States and Mexico. However, most of this has been along one-sided exploitive lines. The largest and best collections of Mexican ores and minerals, reptilians and amphibians, birds, mammals, and flowering plants reside in such American institutions as the Smithsonian Institution, the American Museum of Natural History, the Chicago Natural History Museum, and Harvard University. American naturalists have contributed most importantly to the regional and taxonomic botany, zoology, and geology of Mexico; and the collections in American institutions and the monographs based on these collections have been of service to Mexican scientists. However, very little real co-operation between Mexicans and Americans existed until recently. On the positive side can be mentioned, among others, co-operative surveys for strategic minerals during the war, the survey of game birds and mammals carried out $1943-46$ by the Conservation Section of the Division of Agricultural Co-operation of the Pan American Union, the International Committee for the Study of the Parícutin Volcano, and co-operative projects in tidal studies, meteorology, magnetism, gravity anomalies. Most of the co-operative projects have been with the Mexican Comisión Impulsora y Coordinadora de la Investigación Científica, the various scientific institutes of the Mexican National University, and several departments of the Mexican Government. Along strictly academic lines there is as yet little concern in Mexico about the geology, botany, and zoology of the 
United States, and but little more in American universities concerning these elements in Mexico. There are practically no courses given on the natural history of Mexico, and but a few dissertations (chiefly in economic geology) have been submitted on Mexican subjects. In the fields of the earth and biologic sciences there is especial need for fomenting exchanges of professors, students and publications. Some advance has been made in Mexican membership in scientific societies of the United States, and a sprinkling of American ${ }^{2}$ members are to be found in the various Mexican scientific societies.

\section{CONCLUSION}

It is apparent that among the academic disciplines discussed, history and historians dominate numerically. In terms of close co-operation with Mexicans, the anthropologists lead. The fields with the brightest. future at the moment are economics and all of the applied sciences. Glaring weaknesses appear in the study of the internal history of independent Mexico, in that of local and state government, in nearly all phases of geography and sociology, in rural economics, and in physical anthropology. Outside of history there are exceedingly few regional courses on

2 Should any Latin Americans chance to read these lines, they should be advised that I used the terms "America" and "Americans" instead of "the United States" and "citizens of the United States" for the sake of brevity and because this paper was originally delivered before an audience of North Americans.
Mexico offered in the United States, and in Mexico there are practically no regional courses on the United States. Only in anthropology has there been reached even a minimum of desirable co-operation, acquaintance, membership in societies, exchange of publications, or interchange of professors and students.

If I were to suggest methods of improving scientific and cultural relations between the United States and Mexico I would make five: (1) reduce the number of American tourists and summer school students; (2) prohibit the publication of popular articles on Mexico by anyone who has lived less than a year in Mexico, or who does not have the Spanish; (3) increase and improve the teaching of Spanish in the United States and of English in Mexico; (4) increase manifold the exchanges of mature graduate students and of competent bilingual professors; and (5) improve to parity with Anglos the treatment and standard of living of Mexicans and SpanishAmericans in the United States. I realize that most of the above suggestions are not feasible and some are even absurd--but they illustrate my feelings in the matter. Actually, I believe that there will not be mutual understanding, respect and admiration between the masses of the United States and Mexico as long as the United States and Mexico are contiguous, or as long as the United States is English-speaking, predominantly Protestant, and larger and richer and more powerful than Mexico, or as long as the memory of history endures.

Donald D. Brand, Ph.D., is professor of geography at the University of Michigan, Ann Arbor. He has spent most of the past 20 years in the Southwest and Mexico. From 1934 until 1947 he was professor of anthropo-geography and head of the department of anthropology at the University of New Mexico, Albuquerque. During the years 1944-46 he was cultural geographer in Mexico for the Institute of Social Anthropology of the Smithsonian Institution. His major fields are the historical and economic geography of Latin America. He is author of numerous articles and monographs in these fields. 